\title{
A Morphological Study of the Ultimobranchial Body in the Grass Parakeet
}

\author{
Isamu TAKAGI and Keiki YAMADA \\ Department of Anatomy (Prof. I. TAKAGI), Fujita-Gakuen Health University School of Hygiene, \\ Toyoake, Aichi, Japan
}

Received January 7, 1984

\begin{abstract}
Summary. As parafollicular cells can be stained by Grimelius' silver impregnation and by lead-hematoxylin, the ultimobranchial body cells, homologous to them, seem to also react positively to these methods. In the present study of the ultimobranchial body of the grass parakeet, mirror-image sections were stained by both methods and compared. While about $50 \%$ of the cells reacted positively to both Grimelius' silver impregnation and lead-hematoxylin staining, only about $20 \%$ were positive to the former and about $30 \%$ were positive to the latter only. This result indicating heterogeneity among the cells of the ultimobranchial body of the grass parakeet suggests a possible occurrence of cells secreting substances other than calcitonin.
\end{abstract}

It is well-known that the ultimobranchial body of mammals exists only during the fetal stage and then merges into the thyroid gland shortly before birth. Soon after this mergence, parafollicular cells come into existence in the area where the ultimobranchial body disappeared. Thus, it has frequently been suggested that the parafollicular cells have an endodermal origin; i.e., ultimobranchial origin (GodwIN, 1937; SATo, 1959; Pearse and Carvalheira, 1967; Sugiyama et al., 1969). Pearse and Polak (1971), on the other hand, have suggested that some cells of neural crest origin move into the ultimobranchial body to develop into parafollicular cells, and thus claim a neuroectodermal origin for the cells.

Unlike the ultimobranchial body of mammals, that of lower vertebrates-including birds-remains independent of the thyroid gland after birth, being involved in the secretion of calcitonin, similar to the parafollicular cells (Dudley, 1942; SeHE, 1960; Copp et al., 1967; Chan et al., 1969). PeARSE $(1966,1968,1969)$ has long been advocating the amine precursor uptake and decarboxylation (APUD) theory by noting the existence of serotonin (5-HT), an amine, in addition to calcitonin in the parafollicular cells and the ultimobranchial body. The existence of somatostatin, a peptide hormone, in parafollicular cells has also been recently confirmed in a number of animals (HöKFELT et al., 1975; Noorden et al., 1977; Yamada et al., 1977; Buffa et al., 1979; Alumets et al., 1980; Kusumoto, 1980). Furthermore, the existence of tyrosin hydroxylase (TH), a catecholamine-synthesizing enzyme, in the parafollicular cells of the dog and in the ultimobranchial body of the grass parakeet has been confirmed by the present authors (YAMADA et al., 1983) by using an immunofluorescent method, thus supporting the 
existence of these cells as being of the neuroectodermal origin suggested by PEARSE. It has been now made clear that parafollicular cells and the ultimobrancial body contain various peptide hormones and amines.

In the field of light microscopy, various attempts have been made to differentiate parafollicular cells by staining. Today, Grimelius' silver impregnation (Grimerius, 1968) and lead-hematoxylin (Solcia et al., 1969) are widely used for staining parafollicular cells, although it has been pointed out that these methods may not be effective for the cells of all animals (BuFfa et al., 1979).

In this connection, it was hypothesized that if these two methods were effective for staining parafollicular cells, they should also be suitable for the ultimobranchial body, which possesses secretory functions similar to the parafollicular cells. Accordingly, the ultimobranchial bodies of the grass parakeet as well as quail were subjected to these two methods. This study was considered to form the basis for immunohistochemical and electron microscopic studies presently being carried out by the authors.

\section{MATERIALS AND METHODS}

The grass parakeets used in this experiment were about $15 \mathrm{~cm}$ in length and $30-40 \mathrm{~g}$ in weight. The anesthetized grass parakeets were incised from the cervical region to the throax, and the thyroid glands and the surrouding tissues including the trachea, esophagus, and blood vessels were removed. The tissues were fixed with a GPA solution for $3 \mathrm{hrs}$., embedded in paraffin, made into horizontal mirror-image sections of $6 \mu \mathrm{m}$, and subjected to hematoxylin-eosin staining, PAS reactioning, Grimelius' silver impregnation, and lead-hematoxylin staining. As control samples, parafollicular cells of the thyroid gland of the dog were stained by Grimelius' silver impregnation and leadhematoxylin. The measurement of the ultimobranchial body and other organs was carried out on the hematoxylin-eosin stained samples. The ventro-dorsal depth and left-right width were measured with a manometer for microscopes and on micrographs. The cranio-caudal length was computed out by multiplying the thickness of a segment by the number of the segments. Based on the data obtained, a schema was drawn up

Table 1. Measurements of the neck organs in $\mu \mathrm{m}$ in the grass parakeet (body weight about $34 \mathrm{~g}$ )

\begin{tabular}{ccccc}
\hline & & Cra-Cau & Ven-Dor & L-R \\
\hline \multirow{4}{*}{$\mathrm{L}$} & $\mathrm{T}$ & 1164 & 795 & 719 \\
& $\mathrm{P}$ & 831 & 588 & 534 \\
& $\mathrm{C}$ & 351 & 367 & 340 \\
& $\mathrm{U}$ & 594 & 439 & 341 \\
\hline & $\mathrm{T}$ & 1254 & 890 & 663 \\
$\mathrm{R}$ & $\mathrm{P}$ & 1042 & 548 & 668 \\
& $\mathrm{C}$ & 470 & 281 & 286 \\
& $\mathrm{U}$ & 318 & 143 & 209
\end{tabular}

L: left side organs, $\mathrm{R}$ : right side organs, $\mathrm{T}$ : thyroid gland, $\mathrm{P}$ : parathyroid gland, C: carotid body, U: ultimobranchial body, Cra-Cau: craniocaudal length, Ven-Dor: ventro-dorsal thickness, L-R: left and right breadth. 


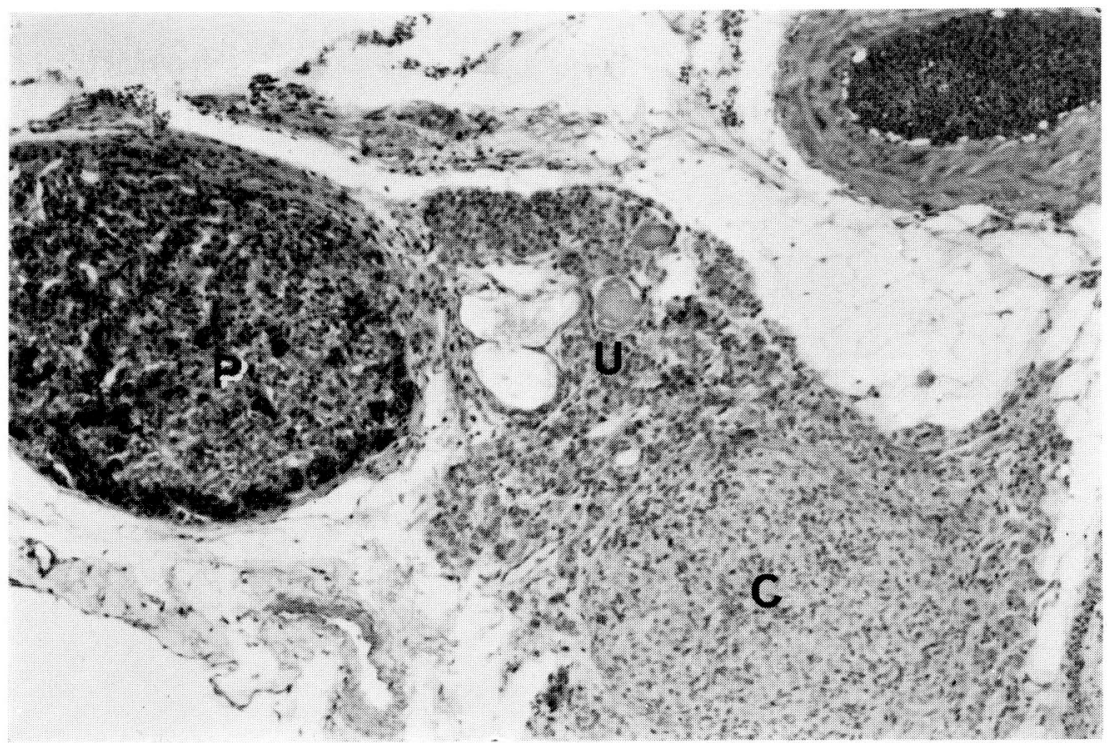

Fig. 1. Light micrographs of an ultimobranchial body $(U)$, carotid body $(C)$ and parathyroid gland $(P)$ in the grass parakeet. Hematoxylin-eosin staining. $\times 150$

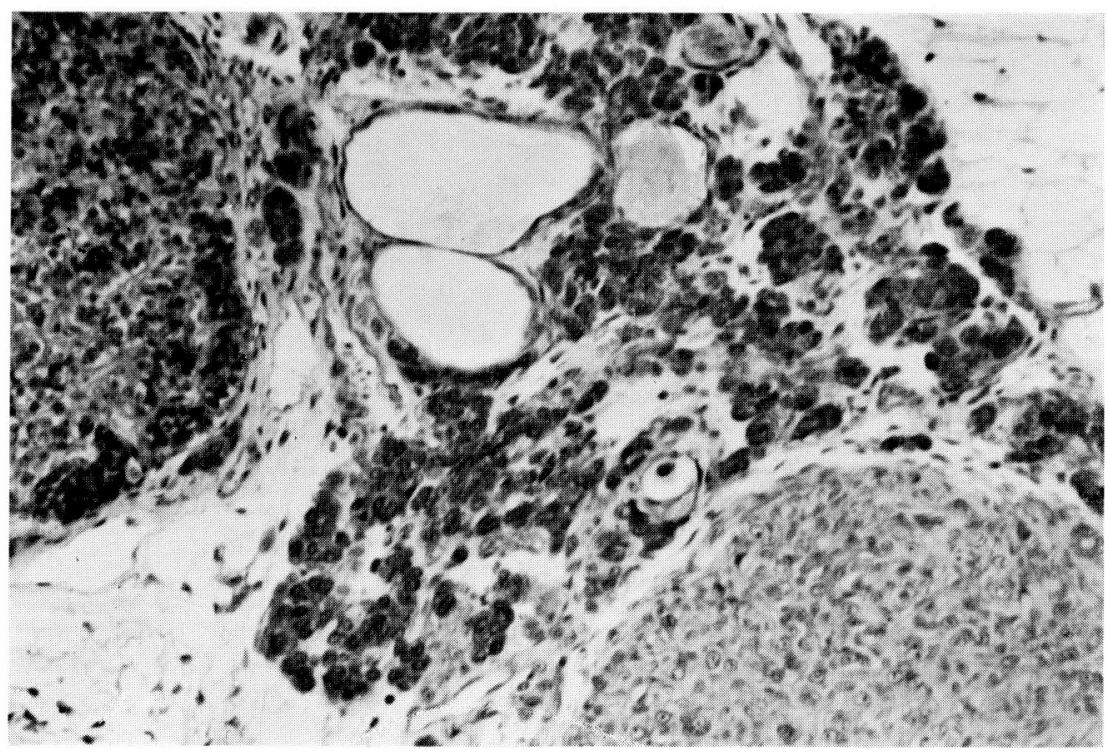

Fig. 2. Higher magnification of the ultimobranchial body. Solcia's lead-hematoxylin staining. $\times 300$

showing various organs in the cervical region and their positions in relation to one another.

\section{RESULTS}

The shapes of the thyroid gland, parathyroid gland, and carotid body of the grass para- 


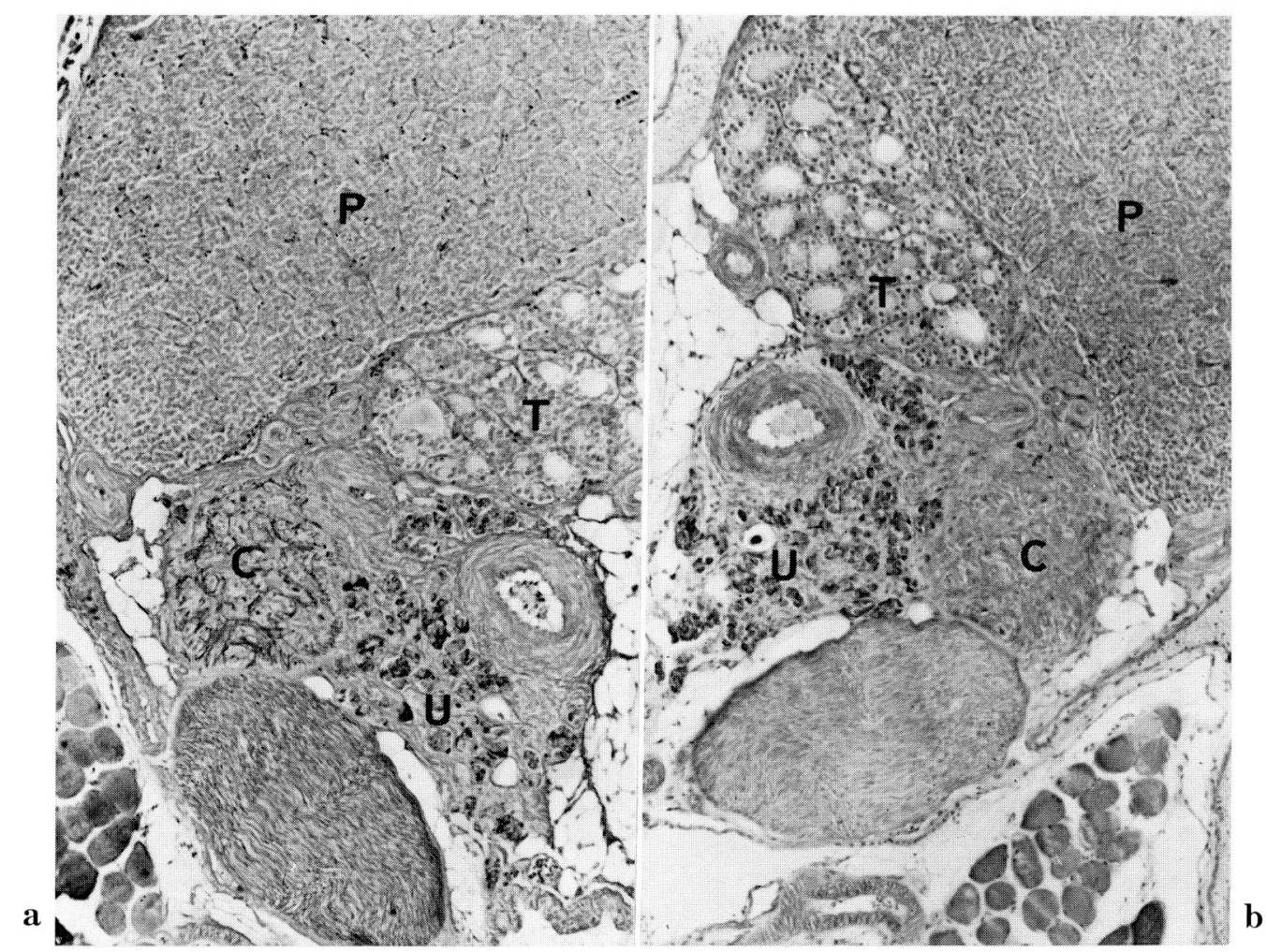

Fig. 3. Light microscopic mirror-image pictures of an ultimobranchial body (U), carotid body $(C)$, parathyroid gland $(P)$ and thyroid gland $(T)$ in the grass parakeet. $\times 120 \quad$ a. Solcia's leadhematoxylin staining, b. Grimelius' silver impregnation in a subsequent section of Figure 3a.

keet were either ovoid or spherical. In contrast, the ultimobranchial body was irregular in shape. This irregularity in the shape might be related to the lack of a capsule around the ultimobranchial body (Fig. 1,2). The ultimobranchial bodies were located near the bifurcation of the branchiocephalic artery and the common carotid artery, and lay parallel to the carotid artery and carotid vein. Adjacent to the vagus nerve, and located in a descending order were the thyroid gland, parathyroid gland, carotid body, and ultimobranchial body. The organs on the left side were located closer as a whole to the pileum than those on the right side. The thyroid gland and the parathyroid gland were often found adjacent to each other. Slightly apart from those organs were the carotid body and the ultimobranchial body. The ultimobranchial body on the left was generally better developed than that on the right, but the other organs showed virtually no differences in size. The thyroid gland was the largest of all the organs, and the parathyroid gland second largest. The third and fourth largest organs differed on the left and right sides; i.e., on the left side the ultimobranchial body was the third largest and the carotid body the forth, but on the right side this order was reversed (Table 1).

A histological examination revealed that the ultimobranchial body had no capsules. Some cells existed independently, while others formed clusters connected by connective tissues rich in capillary vessels. Follicles of various sizes formed by single-layered 


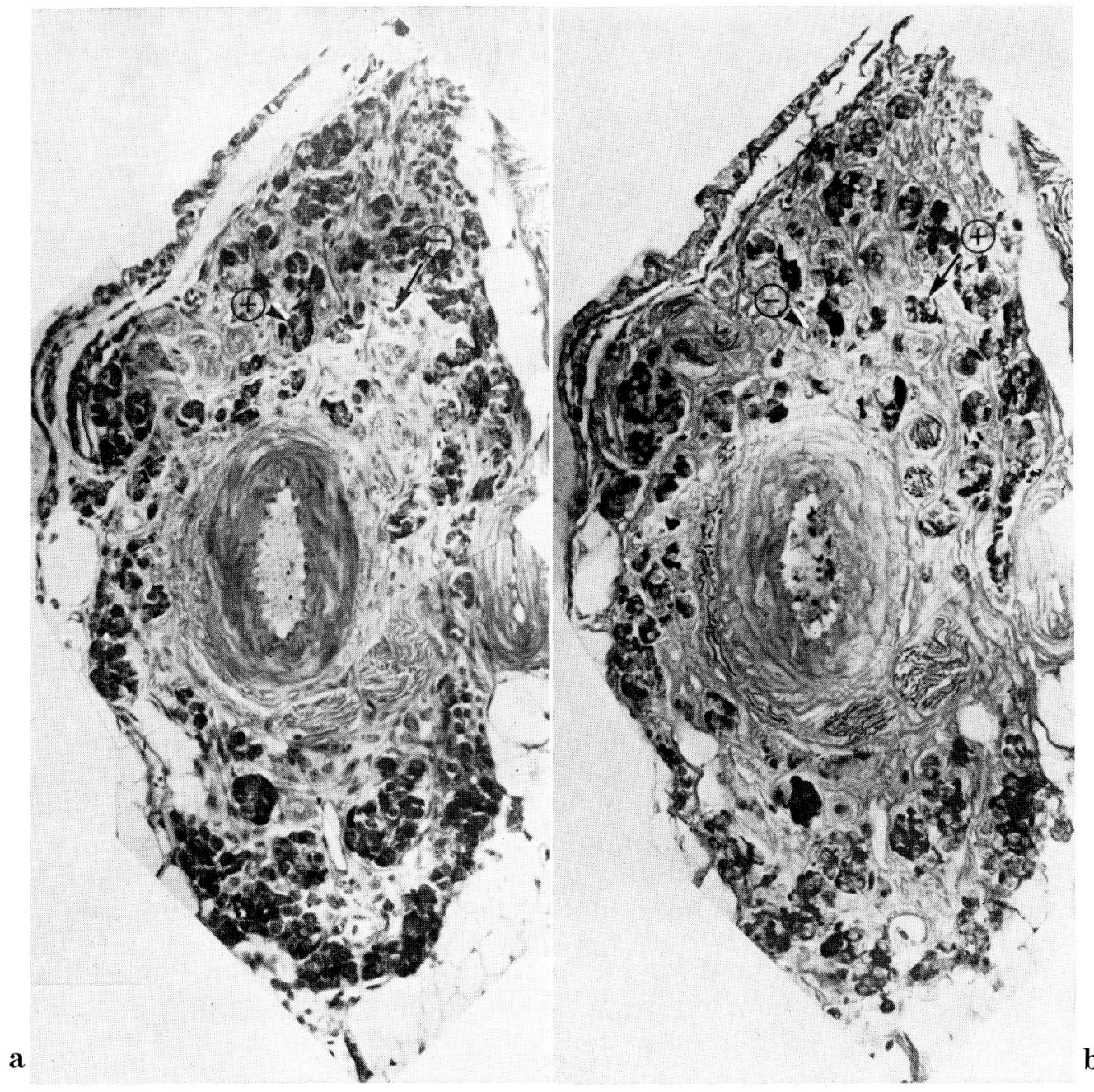

Fig. 4. a and b. Light micrographs in serial sections of an ultimobranchial body in the grass parakeet. a. Solcia's lead-hematoxylin staining. b. Grimelius' silver impregnation. Arrow heads: Lead-hematoxylin positive and Grimelius negative cell clusters. Arrows: Grimelius positive and Lead-hematoxylin negative cell clusters.

follicular cells were also observed (Fig. 1,2). There were colloidal substances and cellular debris in the follicular lumen (Fig. 2).

The ultimobranchial body was distinguished from the other organs by hematoxylineosin staining. The shapes of the cells were either spherical or ovoid. The nucleus appeared light and the cytoplasm was stained in a reddish color (Fig. 1). The colloidal substances in the follicular lumen and some of the connective tissues reacted positively to PAS staining. Grimelius' silver impregnation and lead-hematoxylin staining produced different results depending on the time of fixation. Samples fixed for 3 hrs were stained much better than those fixed for $6 \mathrm{hrs}$ or for $24 \mathrm{hrs}$. In either method, only the cytoplasm reacted positively; the nucleus showed no reaction (Fig. 3, 4). Follicular cells, cilia of the follicular cells, and the colloidal substance and cellular debris in the follicle showed no reactions to either method. Examination of the mirror-image sec- 
tions revealed that, among the cells which showed some kind of stain ability, about $50 \%$ reacted positively to both Grimelius' silver and lead-hematoxylin, about $20 \%$ only to Grimelius, and about 30\% only to lead-hematoxylin. There were a considerable number of cells showing no reactions to either method (Fig. 4).

\section{DISCUSSION}

There have been a number of reports on the ultimobranchial body of the chicken, with the themes of discussion varying from its origin to the ultrastructure (STOECKEL and Porte, 1967, 1969; Malmovist et al., 1968; Chan et al., 1969; Chan, 1971, 1978; YoushaK and CAPEN, 1971; IsLER, 1973). Since there has been no report on the grass parakeet, a comparison beetween the chicken and the grass parakeet was made in this paper.

A brief diagram describing the location of organs was presented by DuDLEY (1942), with more detailed diagrams by Nickel et al. (1977) including the sizes of the ultimobranchial bodies of the chicken, goose, and pigeon.

The location of the ultimobranchial body and the relative sites of the thyroid gland, parathyroid gland, and carotid body in the grass parakeet matched those of the chicken (STOECKel and PorTe, 1967). The size of the ultimobranchial body of the grass parakeet was considerably smaller than that of the birds reported by Nickel et al. (1977), a fact easily accounted for when considering the body sizes of the birds.

The fact that the organs on the left side were located closer to the pileum than those on the right side and that the ultimobranchial body on the left was better developed than that on the right coincided with the data on reptiles.

Concerning the secretory functions of the ultimobranchial body, WATZKA (1933) suggested the possibility of an endocrine function for this organ, and Copp et al. (1967) reported the secretion of calcitonin based on their experiment. By immunofluorescence methods, the present authors confirmed the occurrence of calcitonin and tyrosine hydroxylase in the cells of the body (YAMADA et al., 1983).

The ultimobranchial body of the grass parakeet was histologically characterized by its forming cell groups lacking a capsule and rich in connective tissues and capillary vessels. These characteristics were similar to those of fish and reptiles (TAKAGI and YAmADA, 1977, 1982).

The existence of follicles noted by HodGes et al. (1971) was confirmed in this study, which revealed a number of follicles of various sizes formed by cylindric or cubic follicular cells possessing cilia. PAS-positive colloidal substances and cellular debris were recognized in the follicular lumen. NAGY and SwARTZ (1966) also found PAS-positive substances in the follicular lumen of the chicken. HodGes et al. (1971) observed follicles with substances containing complex acid mucopolysaccharides and mucoproteins, but found no traces of secretion. Reports by ALMQVisT et al. (1971) and IsLER (1973) concluded that these follicles had no relation to the secretion of calcitonin. Though YoushaK and CAPEN (1971) and IsLER (1973) made references to substances resembling cellular debris, they claimed that the follicles were not related to the secretion of calcitonin. As has already been noted by the present authors, the secretion of calcitonin is more likely related to the cell clusters rich in capillary vessels.

Buffa et al. (1979) applied Grimelius' silver impregnation and Davenport's improved method to thyroid parafollicular cells in the dog, guinea pig, rabbit and human and observed that the parafollicular cells of all mammals except the rabbit reacted positively to both methods. The parafollicular cells of the rabbit, which showed histo- 
logical similarities to the pancreatic D-cells, reacted positively to Davenport's improved method but negatively to Grimelius' method. They contained both calcitonin and somatostatin; i.e., approximately $80 \%$ of the calcitonin immunoreactive cells reacted to the anti-somatostatin sera. According to Buffa et al. (1979), however, the parafollicular cells of the other animals, and including man, were positive only for calcitonin.

KAMEDA (1968) subjected the parafollicular cells of the dog and rat to Davenport's improved method and found that the number of parafollicular cells per 100 follicular cells was far greater than the number counted after the conventional staining method (RoHR and HASLER, 1968). MATUZAw A (1966) studied the ultrastructure of the parafollicular cells of the rat and reported that the secretory granules in these cells appeared dark when they were double-fixed with glutaraldehyde and osmium tetroxide, while they appeared as vacuoles when fixed with osmium tetroxide alone. The same was true in D-cells of the pancreatic islets.

Considering the data in the reports mentioned above and the present finding that while about $50 \%$ of the cells reacted positively to both Grimelius and lead-hematoxylin, and, about $20 \%$ reacted to Grimelius only and about $30 \%$ reacted positively to leadhematoxylin only, there seems to be a possibility that the ultimobranchial body of the grass parakeet contains cells which might secrete substances thoer than calcitonin. This problem must be elucidated by immunofluorescent methods.

\section{REFERENCES}

Almqvist, S., E. Malmqvist, C. Owman, M. Ritzen, F. Sundler and G. Swedin : Dopamine synthesis and storage, calcium-lowering activity, and thyroidal properties of chicken ultimobranchial cells. Gen. comp. Endocrinol. 17: 512-525 (1971).

Alumets, J., R. Håkanson, G. Lundqvist, F. Sundler and J. Thorell : Ontogeny and ultrastructure of somatostatin and calcitonin cells in the thyroid gland of the rat. Cell Tiss. Res. 206: 193-201 (1980).

Buffa, R., J. A. Chayvialle, P. Fontana, L. Usellini, C. Capella and E. Solcia : Parafollicular cells of rabbit thyroid store both calcitonin and somatostatin and resemble gut D cells ultrastructurally. Histochemistry 62: 281-288 (1979).

Chan, A. S.: Fine structure of the ultimobranchial gland in the chick. Proc. Electron Microsc. Soc. Amer. 29: 410-511 (1971).

: Ultrastructure of the ultimobranchial follicles of the laying chicken. Cell Tiss. Res. 195: 309-316 (1978).

Chan, A. S., J. D. Cipera and L. F. Belanger: The ultimobranchial gland of the chick and its response to a high calcium diet. Rev. Can. Biol. 28: 19-31 (1969).

Copp, D. H., D. W. Cockeroft and Y. Kueh : Calcitonin from ultimobranchial gland of dogfish and chickens. Science 158: 924-925 (1967).

Dudley, J.: The development of the ultimobranchial body of the foel, Gallus domesticus. Amer. J. Anat. 71: 65-97 (1942).

Godwin, M. C.: Complex IV in the dog with special emphasis on the relation of the ultimobranchial body to interfollicular cells in the postnatal thyroid gland. Amer. J. Anat. 60: 299-339 (1937).

Grimelius, L.: A silver nitrate stain for $\alpha_{2}$ cells in human pancreatic islets. Acta Soc. Med. Upsal. 73: 243-270 (1968).

Hodges, R. D.: The histochemistry of the avian parathyroid and ultimobranchial glands. I. Carbohydrates and proteins. Histochem. J. 3: 339-356 (1971).

Hökfelt, T., S. Efendić, C. Hellerström, O. Johansson, R. Luft and A. Arimura: Cellular localization of somatostatin in endocrine-like and neurons of the rat with special references to 
the $A_{1}$ cells of the pancreatic islets and to the hypothalamus. Acta endocrinol. 80, Suppl. 200: 1-40 (1975).

Isler, H. : Fine structure of the ultimobranchial body of the chick. Anat. Rec. 177: 441-460 (1973).

Kameda, Y.: Parafollicular cells of the thyroid gland as studied with Davenport's silver impregnation. Arch. histol. jap. 30: 83-94 (1968).

Kusumoto, Y.: Calcitonin and somatostatin are localized in different cells in the canine thyroid gland. Biomed. Res. 1: 237-241 (1980).

Malmqvist, E., L. E. Ericson, S. Almqvist and R. Ekholm: Granulated cells, uptake of amine precursors, and calcium lowering activity in the ultimobranchial body of the domestic fowl. J. Ultrastr. Res. 23: 457-461 (1968).

Matsuzawa, T.: Experimental morphological studies on the parafollicular cells of the rat thyroid gland, with special reference to the source of thyrocalcitonin. Arch. histol. jap. 27: 521-544 (1966).

Nagy, F. and G. E. Swartz: The ultimobranchial body of the chick embryo. Trans. Amer. Microsc. Soc. 85: 485-505 (1966).

Nickel, R., A. Schummer and E. Seiterle: Anatomy of domestic bird. Verlag Paul Parey, Berlin, 1977 (p. 108-113).

Noorden, S. V., J. M. Polak and A. G. E. Pearse : Single cellular origin of somatostatin and calcitonin in the rat thyroid gland. Histochemistry 53: 243-247 (1977).

Pearse, A. G. E.: $\quad$ 5-Hydroxytryptophan uptake by dog thyroid ' $\mathrm{C}$ ' cells, and its possible significance in polypeptide hormone production. Nature 211: 598-600 (1966).

: Common cytochemical and ultrastructural characteristics of cells producing polypeptide hormones (the APUD series) and their relevance to thyroid and ultimobranchial $\mathrm{C}$ cells and calcitonin. Proc. Roy. Soc. 170: 71-80 (1968).

-: The cytochemistry and ultrastructure of polypeptide hormone-producing cells of the APUD series and the embryologic, physiologic and pathologic implications of the concept. J. Histochem. Cytochem. 17: 303-313 (1969).

Pearse, A. G. E. and A. F. Carvalheira: Cytochemical evidence for an ultimobranchial origin of rodent thyroid C cells. Nature 241: 929-930 (1967).

Pearse, A. G. E. and J. M. Polak : Cytochemical evidence for the neural crest origin of mammalian ultimobranchial C cells. Histochemie 27: 96-102 (1971).

Rohr, H. P. and K. Hasler: The parafollicular cells of the thyroid gland as a possible site of production of thyrocalcitonin. An electron-microscopic examination of the thyroid of the rat after stimulation by calcium acetate and vitamine $D_{3}$. Experimentia 24: 152-153 (1968).

Sato, T.: The postnatal histogenesis of the thyroid gland of the golden hamster (Cricetus auratus). Okajimas Fol. anat. jap. 33: 225-253 (1959).

Sehe, C. T.: Radioautographic studies on the ultimobranchial and thyroid gland in vertebrates; Fishes and amphibians. Endocrinology 67: 674-684 (1960).

Solcia, E., C. Capella and G. Vassallo: Lead-haematoxylin as a stain for endocrine cells. Significance of staining and comparison with other selective methods. Histochemie 20: 116-126 (1969).

Stoeckel, M. E. and A. Porte: Sur l'ultrastructure des corps ultimobranchiaux du poussin. C. r. Acad. Sci. (Paris) 265: 2051-2053 (1967).

- : Etude ultrastructural des corps ultimobranchiaux du poulet. I. Aspect normal et développement embryonnaire. Z. Zellforsch. 94: 495-512 (1969).

Sugiyama, S., J. Kitoh and S. Yokota: On the problem of the development of the parafollicular cells from the human ultimobranchial body in prenatal life. Okajimas Fol. anat. jap. 46: 59-63 (1969).

Takagi, I. and K. Yamada : An electronmicroscopic study of the ultimobranchial body of the crucian carp (Carassius carassius). Okajimas Fol. anat. jap. 54: 205-228 (1977).

_- : Light and electron microscopic studies on ultimobranchial body of softshelled turtle. Okajimas Fol. anat. jap. 59: 231-246 (1982).

Watzka, M.: Vergleichende Untersuchungen über den ultimobranchialen Körper. Z. mikrosk-anat. Forsch. 34: 485-533 (1933). 
Yamada, K., I. Takagi, Y. Kondo, N. Karasawa and I. Nagatsu : Immunofluorescence studies on catecholamine-synthesizing enzymes and calcitonin in ultimobranchial bodies of grass parakeets and quails. Biomed. Res. 4: 1-8 (1983).

Yamada, Y., S. Ito, Y. Matsubara and S. Kobayashi : Immunohistochemical demonstration of somatostatin-containing cells in the human, dog and rat thyroids. Tohoku J. exp. Med. 122: 8792 (1977).

Youshak, M. S. and C. C. Capen : Ultrastructural evaluation of ultimobranchial glands from normal and osteopetrotic chickens. Gen. comp. Endocrinol. 16: 430-442 (1971).

\author{
高木勇 \\ 干470-11 愛知県豊明市沓掛町田楽ケ宔 1-98 \\ 藤田学園保健衛生大学衛生学部 \\ 解剖学教室
}

Dr. Isamu TAKAGI

Department of Anatomy

Fujita-Gakuen Health University

School of Hygiene

Kutsukake-machi, Toyoake

Aichi, 470-11 Japan 